\title{
ERRATUM
}

\section{The discovery and mechanism of action of letrozole}

\author{
Ajay S. Bhatnagar
}

Published online: 13 December 2007

(C) Springer Science+Business Media, LLC. 2007

\section{Erratum to: Breast Cancer Res Treat (2007) 105(Suppl 1)} DOI 10.1007/s10549-007-9696-3

Due to an oversight, Financial Disclosure of the Authors in the above referenced supplement was not published as required. All authors have acknowledged and signed a

statement of Financial Disclosure/Conflict of Interest and certify that no honoraria for the work therein were received.

The online version of the original article can be found under doi:10.1007/s10549-007-9696-3.

A. S. Bhatnagar $(\square)$

World Wide Services Group Ltd, Geispelgasse 13,

4132 Muttenz, Switzerland

e-mail: ajay.bhatnagar@wwsgroup.com 